Discussion Paper No. 04-70

\title{
Decision-Making of the ECB: Reform and Voting Power
}

Katrin Ullrich

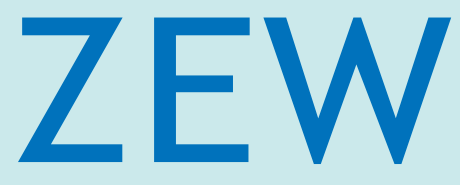

Zentrum für Europäische Wirtschaftsforschung $\mathrm{GmbH}$

Centre for European

Economic Research 
Discussion Paper No. 04-70

\title{
Decision-Making of the ECB: Reform and Voting Power
}

\author{
Katrin Ullrich
}

Download this ZEW Discussion Paper from our ftp server:

ftp://ftp.zew.de/pub/zew-docs/dp/dp0470.pdf

Die Discussion Papers dienen einer möglichst schnellen Verbreitung von neueren Forschungsarbeiten des ZEW. Die Beiträge liegen in alleiniger Verantwortung der Autoren und stellen nicht notwendigerweise die Meinung des ZEW dar.

Discussion Papers are intended to make results of ZEW research promptly available to other economists in order to encourage discussion and suggestions for revisions. The authors are solely responsible for the contents which do not necessarily represent the opinion of the ZEW. 


\section{Non-technical Summary}

The number of decision makers in the Governing Council of the ECB increases significantly when new EU members join the European Monetary Union. Therefore, a reform is necessary to ensure the efficiency of the decision-making processes. The agreed reform proposal of the ECB is evaluated using different classification criteria to group the governors for asymmetric rotation and the assignment of voting power instead of voting weights to determine the influence the governors of different rotation groups would have on interest rate decisions.

With a growing number of members in the ECB Council, the processes to decide about the interest will be more complex and take considerably more time if the decision-making process is the same as in the status quo. Furthermore, the difference between the economic and political weight will increase. Therefore, the ECB will switch to a rotation scheme if the number of members grows. E.g., if the number of central bank governors would be 25, three groups of governors are formed, where the first group of five members gets four votes, the second 13 members have eight votes and three votes are assigned to the third group of seven governors. Independently of the number of central bank governors in the Council, only 15 governors have voting rights. The members of the board have one vote as hitherto and the president decides in case of a tie.

The rotation scheme is assessed, first, using different economic criteria for the classification of the governors into the different groups and, second, determining the voting power of the Council members using voting power indices, especially the Banzhaf measure and the Banzhaf index.

We analyse how the composition of the three groups changes if not the index of the reform proposal is used but different economic criteria are applied. One possibility would be the synchronisation of the economic development of the countries. The more similar the economic development the more equal are the needs of the countries with regard to monetary policy. The economic development is described by an index calculated as the unweighed average of the inflation rate and the deviation of industrial production from its trend. It is shown that the grouping in terms of the correlation of the country-specific index with the average of the respective monetary union does not lead to a much different situation regarding the allocation of voting rights. Countries with lower economic weight like Austria or Belgium would gain a higher voting weight. But the new member states are mainly allocated into the third group as before.

A second possibility to assess the reform is to calculate the voting power and compare it with the population and economic weight of a country. The voting power reflects the influence a governor can exert on the outcome of a vote on the change 
of the interest rate. For the determination of voting power different indices are used (Shapley-Shubik index, Banzhaf measure, Banzhaf index). Different scenarios are imaginable. One crucial assumption concerns the behaviour of the board. If the board members support the national central bank governors in the votes on the interest rate, the board members behave as national partisans. The voting power suggests that the influence of a board member declines with the enlargement of the Council but rises with the introduction of rotation. The indices of voting power show that the influence could well be higher than in the status quo.

For the national central bank governors, the intertemporal voting weight unveils the same pattern as the voting power indices for most of the time. The evaluation of the classification into three groups shows an adjustment of the economic and political weight in the group three of small countries and in the second group. The first group gains a small amount of political weight with the introduction of the rotation scheme after a loss by the enlarged committee.

As the analysis shows, the use of different economic criteria does not lead to a reversed ordering of the countries and, therefore, to a much different allocation of the governors to the groups compared to the arranged classification scheme. The use of the deviation from the average economic situation would lead to more changes in the group composition than the use of the synchronisation of the economic development. But even then, most of the countries would move into the next higher or lower group. A change from the first to the third group or reverse would be a rare exception. The assessment with regard to the voting power of the Council members depends on the assumption about the behaviour of the board members. With the rotation scheme, the difference between economic and political weight is not much reduced as the comparison of voting power indices in the status quo and an enlarged decisionmaking body shows. 


\title{
Decision-Making of the ECB: Reform and Voting Power
}

\author{
Katrin Ullrich (ZEW Mannheim)*
}

September 2004

\begin{abstract}
The ECB reform is designed to meet the challenges of an enlarged monetary union in the ECB Council. The reform is assessed by analysing alternatives for the classification of governors into groups of the rotation scheme like the synchronisation of the economic development of the member states. In a second approach, voting power indices are assigned to the governors allocated to the different groups instead of voting weights. Special attention is given to the difference between the political weight of a governor and the economic and population weight of its country of origin.
\end{abstract}

JEL Classification: E58

Key Words: ECB, reform, rotation scheme, voting power indices

${ }^{*}$ Centre for European Economic Research, Mannheim, P.O. Box 1034 43, D-68034 Mannheim, Germany; ullrich@zew.de. The author is currently also a scholar at the "WIN-Kolleg" of the Heidelberg Academy of Sciences ("Heidelberger Akademie der Wissenschaften"). The financial support of the Heidelberg Academy of Sciences for the project "Legitimacy of a European Constitution" is gratefully acknowledged. I thank Friedrich Heinemann and Jürgen Wiemers for helpful comments. 


\section{Introduction}

The enlargement of the European Union (EU) by ten members in 2004 and the outlook for a later expansion of the European Monetary Union (EMU) and the possible joining of Denmark, Sweden and UK to the EMU made a reform of the decisionmaking body of the European Central Bank (ECB) acute. The reform proposal of the ECB has been accepted by the Council. The reform provides a rotation of voting rights in different groups of national central bank governors. The board is excluded from rotation. In this paper, we evaluate the reform extensively. First, we analyse the group composition if other than the declared criteria are applied. Second, we look at the difference between the economic and political weight of the countries using voting power indices besides the intertemporal voting share.

The discussion about the reform of the Governing Council of the ECB shows two starting points with regard to the assumptions about the independence of the monetary policy of the ECB:

a) The first point of view is that the members of the Governing Council of the ECB decide on the basis of the economic situation of the euro area as laid down in the statute (Article 108 of the Maastricht Treaty). Then, from an economists' point of view, there is no difference between the status quo and a committee composed of experts which conduct monetary policy for the euro area. Surely, the same economic figures can be interpreted differently by the decision-makers but the dissent should not be too large and an agreement possible. If this description is correct, a reduction of the members of the Governing Council should not be objected by the member states.

b) The second approach is that the country of origin of the Council members matters and the asymmetries in the economic situation and development between the member states can distort the decisions regarding the interest rate. In this case, a governor is not only a distinguished expert with respect to monetary policy but also a representative of its country of origin. Then, another solution to the problem of efficient decision-making in the Governing Council with a growing number of members is necessary. Here, the selection of members who are allowed to vote seems crucial for the results of monetary policy.

In addition to the conditions of efficient decision-making with a large number of decision makers, the representation of the member states is a crucial question. Even if the national central bank governors base their decision on the average euro area situation the question of representation arises. To enhance the approval of central bank decisions by the people of the member states there should be no suspicion with respect to the ECB members pursuing national interest or deciding because of 
political influence of big or small member states. This is important because legitimacy still arises via the member states (Heisenberg 2003). This does not necessarily imply that the representatives pursue national interests but that the Council members represent their country of origin from the view of the citizens. Therefore, there is a trade off between democratic legitimacy and efficient decision-making in the process of denationalisation of voting rights. For Heisenberg (2003) the process of decision-making, especially transparency, secures legitimacy. The legitimacy of denationalisation will be possible if transparency is high enough.

The question of power in the decision-making of the EU within the Commission or the Council of Ministers has attracted far more attention than the power of decision-making in the ECB Council. Previous studies on the subject of the reform of the ECB concentrate either on the analysis of voting weights in the ECB Council ${ }^{1}$ or on the EMU with 11 (EMU-11), 12 (EMU-15) or 15 (EMU-15) member states (Mangano 1999, Brueckner 2001). Fahrholz and Mohl (2004) compare different rotation scenarios with the help of a voting power analysis for the EMU-25. Another source is Bindseil (2001) combining the assessment of voting power with a prediction about potential transfers by monetary policy. Rents from economic integration are distributed according to voting rights. If the number of countries grows, the rule of 'one person - one vote' does not influence the allocation of the rents.

Starting point for the analysis is the proposal for the reform of decision-making of the ECB. From all reform options which are introduced in the next section, the ECB has chosen a rotation scheme for its proposal which the Council of Ministers has accepted. The classification of the governors into different groups whose members have a certain number of votes smaller than group members is done according to the share of aggregated GDP at market prices and the share of the total assets of the balance sheet of Monetary Financial Institutions (TABS-MFI) the country of origin of a governor shows. In the third section, other criteria are used such as the synchronisation of the economic development measured by the correlation with the average of the monetary union or the dispersion of the economic situation. As the results indicate, there are some changes in the classification of countries but no important alteration of the ordering.

The second approach to asses the rotation scheme of the ECB is the calculation of voting power indices and viewing the change of political influence with a growing number of members in the Council. The introduction of rotation changes the political weight once more. As the voting power indices show, the board gains influence whereas the development of political influence of the national central bank

\footnotetext{
${ }^{1}$ Investigations are e.g. the briefing papers for the Committee for Monetary and Economic Affairs (ECON) of the European Parliament, Belke and Baumgärtner 2004, Berger 2002, Berger, de Haan and Inklaar 2003, Berger and Hefeker 2004, Frenkel and Fendel 2003. The enumeration has no claim to be complete.
} 
governors depends partly on the behaviour of the board, e.g. if they are supported by the board members. With the rotation scheme, the difference between economic and political weight is not much reduced as the comparison of voting power indices in the status quo and an enlarged decision-making body shows. The last section concludes.

\section{The Reform of the Decision-Making Procedure of the ECB}

\subsection{The Necessity of the Reform and Reform Options}

The likely joining of countries to the EMU in the future, decision-making of the Governing Council of the ECB will be much more complex after new members have acceded the monetary union. The need for a reform can be summarised by two points (Hefeker 2002): First, with a growing number of members, the efficiency of decision-making will be influenced in two dimensions. The speaking time will increase significantly and prolong meeting time considerably. The decisions itself will be more complex because more governors have to agree to a proposal independently of the decision rule, e.g. if a consensus or majority rule will be used. Second, there is a wedge between the political and economic weight of the countries. If the principle of 'one person - one vote' is maintained, this would lead to an overrepresentation of smaller countries with respect to their economic weight. This over-representation seems problematic because of systematic differences between the economic conditions in small and large countries assuming that the governors decide with an eye on the economic situation in their country of origin (Heisenberg 2003). Heinemann and Hüfner (2004) find empirical support for the hypothesis that regional divergences influence the decisions of the ECB Council on the interest rate. Of special interest in this respect are the board votes. Because it is overall assumed that the board decides with respect to euro area conditions, an increased relative weight of the board votes could help to mitigate the difference between political and economic weight of the nations. On the other hand, over- and under-representation of countries with regard to voting rights could be in line with unemployment and wage setting (Berger and Hefeker 2004).

To solve these two problems, four reform options are analysed in the literature. Because they are investigated in length e.g. in Berger (2002) or Baldwin et al. (2001), we restrict ourselves to a short overview.

The first solution is the centralisation of decision-making by delegating monetary policy to the board or a group of selected experts. In contrast to the national central bank presidents who are undoubtedly experts in monetary policy the connection 
between country of origin and seat in the Council is not that strong. This would solve both of the above-mentioned problems: the number of members could be restricted and the members share a similar view on monetary policy in the euro area. Therefore, the members could be few and decision-making should be fast. Furthermore, the guideline of 'one person - one vote' is preserved.

But there are some disadvantages too: Even the composition of the board is not free of national interests as the discussions about the appointment of new board members show. Furthermore, national representatives in the Council supply a broad view of the economic situation in the euro area and diversified information for the decisions. Therefore, delegation does not necessarily prevent information providing by national central bank governors (Baldwin, Berglöf, Giavazzi, and Widgrén 2001). But the efficiency of this depends on the procedure, e.g. if the governors have the right to speak in the meeting or write briefing papers. Another problem is that the independence of the central bank is better served by a diversified appointment process absorbing preference shocks of the governments. The Council will be composed of governors which are appointed by governments with different preferences leading to a mix of more or less inflation averse members.

The second proposal is to weigh the votes according to some prescribed scheme. A weighted voting can reduce the wedge between political and economic weight of the member states but contradicts the principle of 'one person - one vote'. Hefeker (2002) demands a weighting with regard to population size for the sake of democracy. This does also encompass the possibility to qualify the decision rule by incorporating the need that the votes represent the majority of the people in the EMU (Berger, de Haan, and Inklaar 2003). Nevertheless, the weighting scheme has to be decided.

Representations is the third approach. With representation a group of governors obtains representative votes. The vote allocation can be done by determining the voting rights per group or by delegating the voting right of every group member. The last possibility preserves the 'one person - one vote' principle. This alternative demands group selection and fixing the number of groups. One special form would be extending the competence of regional central banks across national borders (Berger, de Haan, and Inklaar 2003).

The last proposal is to rotate the voting rights of the decision makers. With rotation, the governors lose their permanent voting right. The formal criteria defining the rotation process are the voting periods and the number of group members. Rotation can be done in a symmetric or asymmetric way. The last-mentioned possibility also involves a grouping of the members, where the grouping criteria have to be determined in addition to the rotation scheme. The criteria could be the GDP share, the synchronisation of the business cycle and/or structural inflation (Berger, de Haan, and Inklaar 2003) or the population share. If rotation is bound to the 
economic weight of a country, this could solve for efficient decision-making and the difference between economic and political weight. Furthermore, the whole currency area should be represented as far as possible. A drawback of the grouping could be, that the same economic size of their countries of origin does not necessarily mean that the decision-makers have the same preferences or that the needs of the countries with regard to monetary policy are similar (Hefeker 2002).

Summing up, some of the solutions seem problematic with respect to political feasibility and legitimacy besides the difficulties determining weights or groups: Rotation and delegation reduce the credibility and accountability of the ECB (Baldwin, Berglöf, Giavazzi, and Widgrén 2001, p. 45). If members of the Governing Council are excluded from the decision (process) the democratic legitimacy is reduced (Heisenberg 2003). This is because all member countries are affected by the decisions of a selection of the member states. Here a problem of insiders (members with voting right) and outsiders (members without temporary voting rights) arises (Waldner, Kocher, and Sutter 2003). Furthermore, delegation and rotation need high transparency or the assurance that the remaining decision makers are not prone to national interests. If this could not be supported, Heisenberg (2003) sees representation as more democratic especially if grouping is homogenous. For a summary of pros and cons of different reform options see also Farvaque and Stanek (2003).

\subsection{Reform Realisation}

The reform option accepted by the Council of Ministers for the solution of a rising number of representatives in the ECB Governing Council is asymmetric rotation. The decision of the Council, meeting in the composition of the Heads of State or Government of 21 March 2003 on an amendment to Article 10.2 of the Statute of the European System of Central Banks and of the European Central Bank is as follows:

The principle of 'one person - one vote' is kept up but the number of governors with voting rights will be restrained. This will be implemented via a rotation scheme. The rotation happens within two and, later on, three groups depending on the total number of national bank governors. The groups are formed according to a ranking relying on the share of the aggregated gross domestic product at market prices and the total aggregated balance sheet of the monetary financial institutions of the national central bank's member state which have adopted the euro. The weights assigned are 5/6 and 1/6, respectively. The groups formed by the Council members are assigned to the following voting rights (see Table 1). The rule for decisionmaking has not changed. The Governing Council acts by simple majority of the members having a voting right. In the event of a tie, the President has the casting vote. Decisions can be taken if two third of the Council members are present. 
Table 1: Voting rights of the groups.

\begin{tabular}{|l|c|c||c|c|c|}
\hline total number of governors $\mathrm{n}$ & \multicolumn{2}{|c||}{$18<n<22$} & \multicolumn{3}{|c|}{$n \geq 22$} \\
\hline group & I & II & I & II & III \\
number of governors & 5 & $n-5$ & 5 & n/2 & n-n/2-5 \\
number of voting rights & 4 & 11 & 4 & 8 & 3 \\
\hline
\end{tabular}

This solution has been criticised extensively in the briefing papers of the monetary dialog with the European Parliament (see Bofinger 2003, de la Dehesa 2003, Gros 2003, Horn 2003, Wyplosz 2003), not least because of the secrecy of the process leading to the proposal of the reform. The main critique is that most of the criteria the ECB lists to assess the reform (improve the capacity for decision-making, one member - one vote, ad personam participation, representativeness, robustness, automaticity and transparency), are missed. Furthermore, the proposal does not specify the rotation rules and frequencies within a group which could cause further discussion (Frenkel and Fendel 2003). It says that (Council 2003): "The frequency of voting rights of the governors allocated to the first group shall not be lower than the frequency of voting rights of those of the second group" and "within each group, the governors shall have their voting rights for equal amounts of time". Moreover, the time of voting rights within one group and the terms of office of a governor can be incompatible.

But compared to different rotation schemes, the actual solution is not that bad with respect to difference between economic and political weight (Berger, de Haan, and Inklaar 2003). In the following, we extend the analysis done so far by comparing different methods of group selection by economic criteria and use voting power indices as a second approach.

\section{Grouping of Governors and Voting Power in an Enlarged ECB Council}

\subsection{Economic Development and Voting Weights}

Most of the investigations of the proposal use the intertemporal voting shares to evaluate the reform, see e.g. Belke and Baumgärtner (2004). ${ }^{2}$ The intertemporal voting share is given by the share with which a governor participates on the decisions.

\footnotetext{
${ }^{2}$ One possibility is to treat this as a problem of insider and outsider. Another possibility is the question if rotation harms cooperation within a group and treat the decisions as the same as the provision of a public good with self-interest and common interest (Waldner, Kocher, and Sutter 2003).
} 
For a governor of the first group, this number is $4 / 5$. If rotation takes place, the relative voting weight is calculated as the intertemporal voting share times the voting weight of $1 / \mathrm{n}$ with $\mathrm{n}$ the total number of votes. The president has two votes because he decides in case of a tie, every other Council member has one vote.

As Figure 1 shows, a country's population share does not necessarily match with its relative voting weight. The same is true for its economic weight, see Figure 2. The economic weight is calculated following the ECB proposal (5/6 times the share of the aggregated GDP at market prices plus 1/6 time the share of TABS-MFI for 2003). The data are summarised in the appendix (see Table 11) and reproduce the ordering results from e.g. Gros (2003).

The "big" countries are under-represented and the "small" countries have a higher political weight than their relative population size or economic weight would suggest. The under-representation is more pronounced than the over-representation. There are some slight differences between the representation with regard to the population and to the economic weight.

First, we concentrate on the population weight (See Figure 1). Countries which are member of all four monetary unions have the highest gap in the EMU with 12 member states (EMU-12). With the transition to 15 member states (EMU-15), the number of members rises. This leads to a lower voting weight as well as a lower population share. Because the population share decreases more than the voting weight, gaps are invariably smaller than before. The same picture arises for the monetary unions where the rotation scheme is applied, the EMU with 22 (EMU22 ) and 25 (EMU-25) member states. For governors belonging to the second and third group, the gap between voting weight and size of the population is attenuated for the transition from the status quo voting process to the rotation scheme. For governors of the first group (France, Germany, Italy and Spain), the wedge between population share and voting weight rises with the transition to the rotation scheme because the composition of the union changes. The population share of the countries rises because the UK with a high share is part of the EMU-15 but not the EMU22. At the same time, the voting weight decreases because of a higher number of voters. This leads to a worsening of the proportion of the population share and voting weight.

Second, the gap between the voting weight and the economic weight is viewed (see Figure 2). The pattern of the changing difference between voting and economic weight is almost the same. The most outstanding difference is that for four governors of the first group (France, Germany, Italy and Spain) the gap does not only rise for the transition from the EMU-15 to the EMU-22 but is higher than in the status quo. Furthermore, the wedge for the EMU-25 is higher than in the EMU-15. The difference in the scenarios arises because the economic weight of the ten new member 
states is higher than their population share. Therefore, the economic weight is more reduced than the population share of the old member states with the enlargement of the EMU.

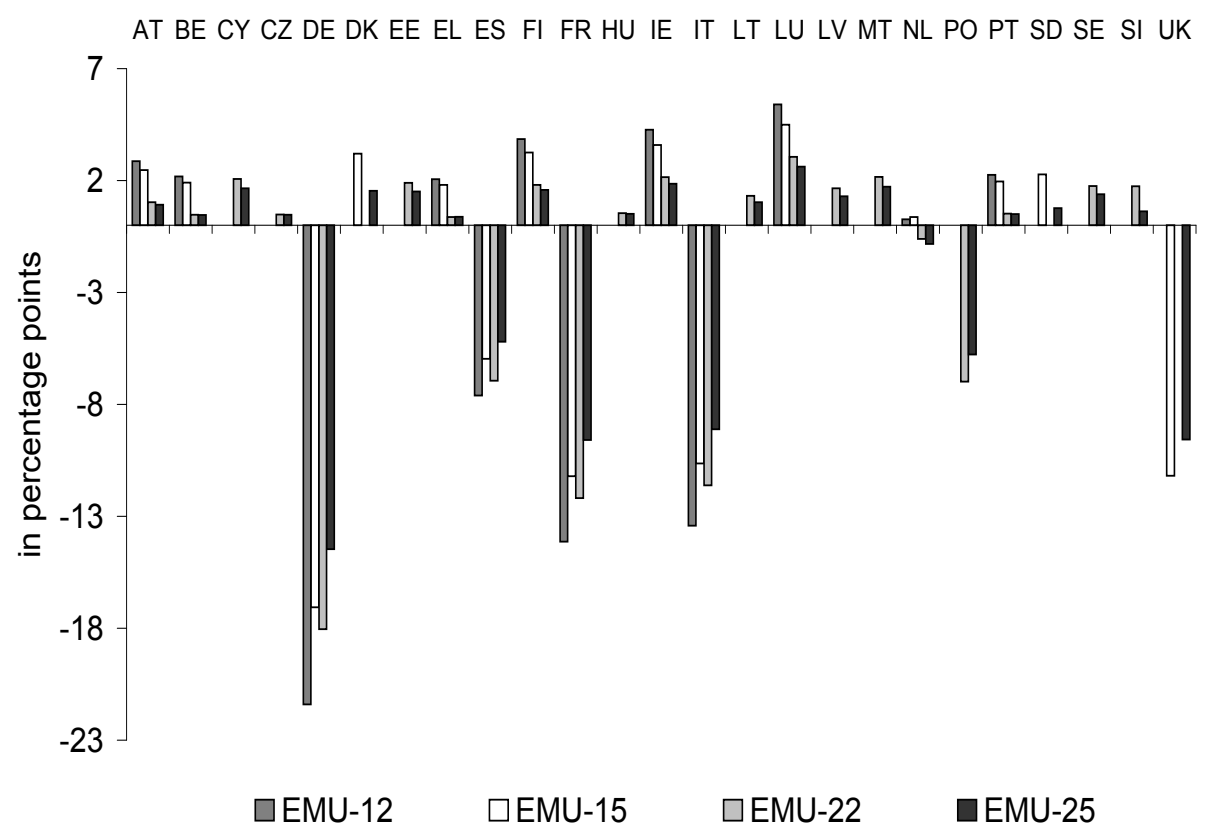

Figure 1: The difference between the voting weight and the population share.

There is a drawback assessing the size of a country in this way. The numbers show the situation in 2003 but to the time of enlarging the EMU the economic situation of the accession countries could be different. But the GDP as well as the TABSMFI will not be as high as in the larger EU countries because of size restrictions. Furthermore, the reform only accounts for the size of a country and, therefore, has a focus on representation. If the interest rate decisions of the Governing Council are regarded, not only the size but the economic situation and its further development matter, e.g. inflation and output gap or output growth would play a role in the decision-making as indicated by the basic Taylor rule (Taylor 1993). Other scenarios are imaginable such as the deviation from the EMU average and the synchronisation of the economic development. These will by analysed in the next two paragraphs.

Deviation from the EMU average One possibility is to change the grouping criteria from GDP share and size of the banking sector to GDP growth and inflation. Inflation is used because a central bank decides about interest rate changes with regard to the inflation rate. The second component used is economic growth. First, economic growth or the output gap hint to future inflation pressure. Second, if 


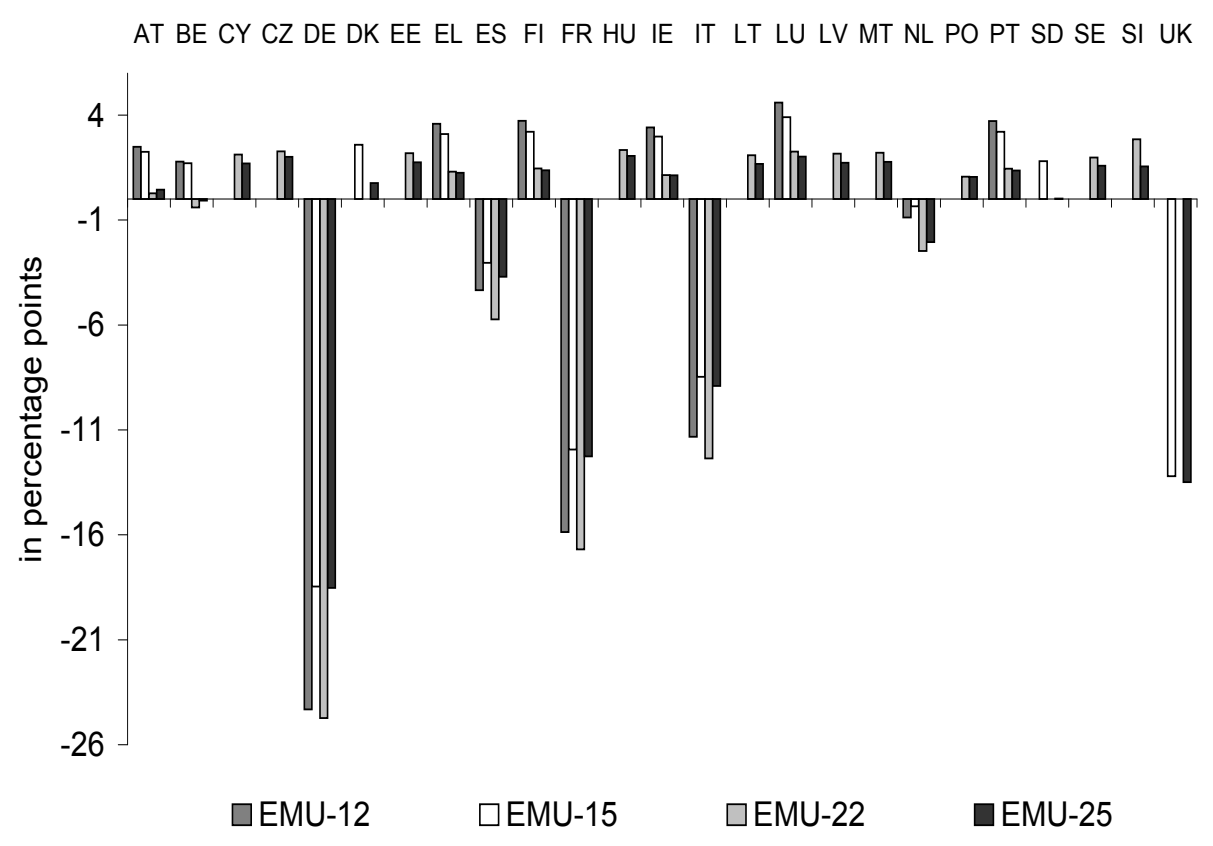

Figure 2: The difference between the voting weight and the economic weight.

the business cycles within one group are relatively similar, one can assume that the governors of this group represent all countries within this group with respect to monetary policy. A scatter plot for the inflation rate and the GDP growth rate in 2003 is shown in Figure 3.

The picture shows the difference in the economic situation of old and new EU members to date. What stands out is that the new EU members are further away from the origin indicating a situation of high growth rates and high inflation rates. Nevertheless, there are economies of this group with high growth and low inflation, e.g. Lithuania, Latvia or Estonia. Slovakia is the outlier with nearly nine per cent inflation and a growth rate of around four per cent. The countries of the EMU-12 and EMU-15 cluster near the origin with lower growth and lower inflation rates. Here, even negative growth rates are noticed, e.g. Portugal, the Netherlands, and Germany.

The countries with high growth rates are prone to the Balassa-Samuelson effect and presumably are located in a catching up process. This process could be supported by a lose monetary policy. On the one hand, this is normally seen in contrast to the "old" member states with low inflation rates and a more restrictive monetary policy. On the other hand, one could ask the question whether the economies of the old members would overcome slow growth with a more expansive monetary policy. 


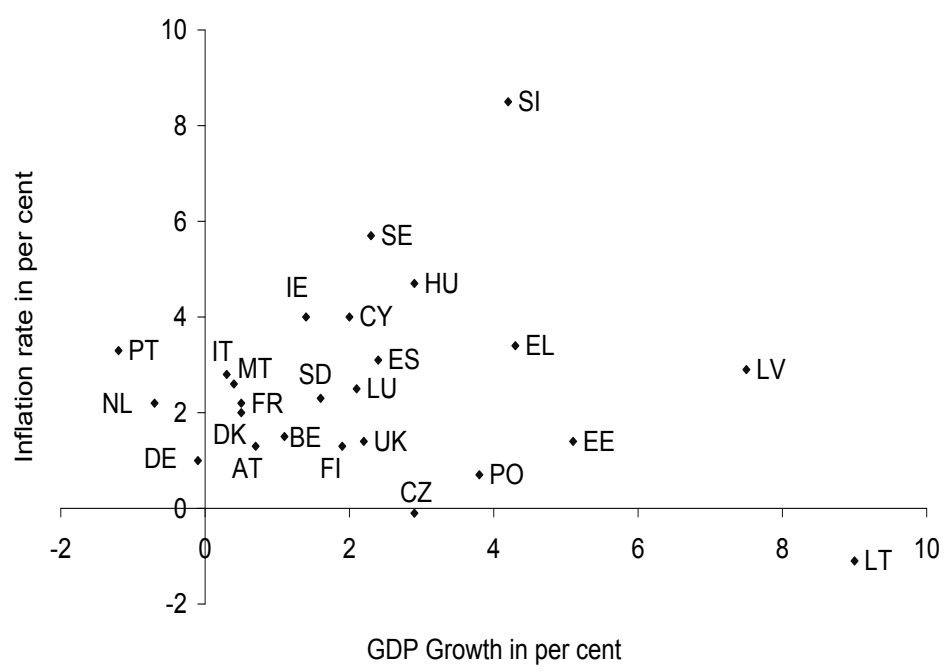

Figure 3: Scatter plot for inflation and GDP growth in 2003 (for abbreviations see appendix). Source: Eurostat Structural Indicators: the growth rate of GDP at constant prices (base year 1995) - percentage change on previous year and the annual average rate of change in Harmonised Indices of Consumer Prices for 2003.

But because the main goal of the ECB is securing price stability in the average, country specific developments only matter if they influence the European average in a significant way.

To assess whether the economic situation in a country represents the EMU average we calculate the share a country has in the total deviation of the average economic situation. The numbers show the dispersion of the economic situation in the monetary union. The economic situation is approximated by an index, es, composed as the average between the inflation rate, $\pi$, and the GDP growth rate, $g_{y}$, es $=\left(\pi+g_{y}\right) / 2$. For the calculation of the country-specific share of the deviation from the European average see appendix (page 27). It shows for how much a country accounts for the dispersion of growth and inflation in per cent.

If we use the relative deviation from the EMU average for grouping of the governors, the composition of the groups changes as shown in Table 2. Countries which account for a small share of the deviation are core countries and are placed in the first group with the highest voting weight. Using the deviation from the average for classification does not count for the size of the country but for the similarity of the economic situation. This makes sense if the national bank governors look at the economic situation in their country of origin when deciding about the interest rate. But even if this is not the case, this kind of scheme has its merits: The core group 
of governors have the highest voting weight and represent the economic situation of the EMU because the countries are near the European average.

Applying the alternative classification scheme leads for half of the governors to a change of the group. The biggest change is for Malta from the third to the first group which leads to a significant rise of voting weight. Additionally, Belgium, the Czech Republic, Cyprus and Estonia are better off in the EMU-22 and the Czech Republic, Cyprus, Finland and Malta in the EMU-25. Worse off are Germany, Greece, the Netherlands, Spain, Hungary and Slovakia in the EMU-22 and the same countries and UK but not the Netherlands and Slovakia in the EMU-25. All in all, some smaller countries change into a group with higher voting weight. Nevertheless, the governors of the third group come from the new EU members as proposed in the rotation scheme of the ECB. Greece as the latest member of the monetary union is part of this group too.

A direct comparison with the voting weight is not possible because a high share from the deviation means less representation in economic terms and the governor of this country should obtain a low voting weight. Again, only the actual economic situation is considered, not the possible development of the situation. This analysis gives only a snap-shot of the economic situation. Furthermore, it is possible, that the economic situation will converge within a sufficient period of time. Then the distinguishing feature of inflation and growth loses its significance. 


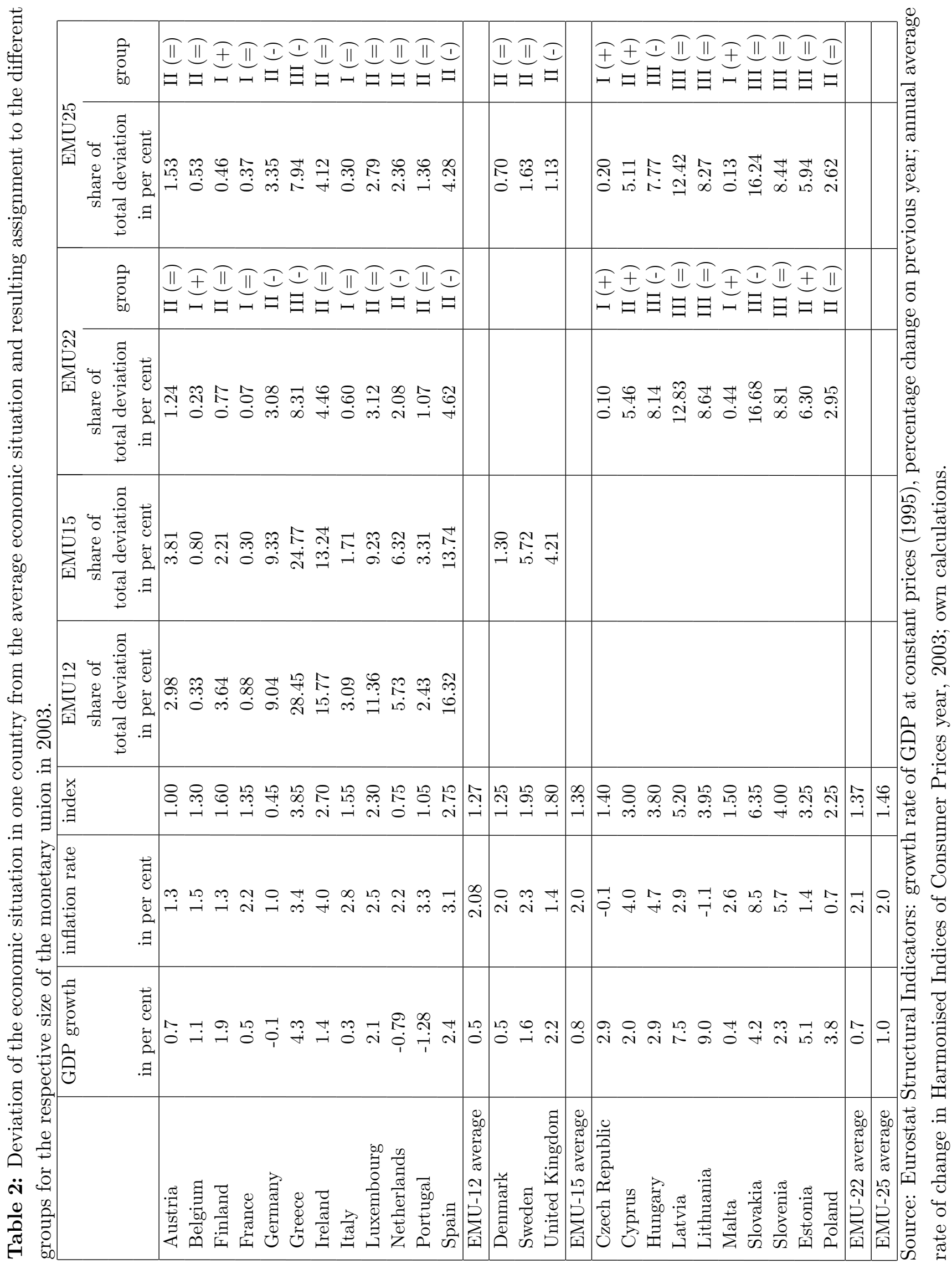


Synchronisation of economic development Another approach to classify the countries would be the synchronisation of the economic development. We analyse the correlation between the economic situation in a country and the average economic situation of the respective monetary union. The economic situation is captured by an index, $(\pi+y) / 2$, calculated as the average of the inflation rate based on the Harmonised Consumer Price Inde ${ }^{3}$ and the deviation of industrial production ${ }^{4}$ from its trend. The latter is calculated by $y=1+\left(i p-i p^{*}\right) / i p^{*}$, where $i p$ is the actual index of seasonal adjusted industrial production and $i p^{*}$ the series of the HodrickPrescott filtered industrial production series. This extends the analysis of Berger et al. (2003) by including the inflation rate into the description of the correlation and combines that of Hefeker (2002) into one index. We could not include Malta because no information on monthly industrial production series was available to us. We use two kinds of EMU averages, the unweighted average and the weighted average. The weights for the calculation of the EMU inflation rate are determined by the countryspecific share of the total household final monetary consumption expenditure. This is the weighting scheme Eurostat uses for the calculation of the HICP. For the series of the industrial production index, also the weighting scheme of Eurostat is used (Eurostat 2004c). The correlation coefficients between the averages of the EMU22 or EMU-25 and the country-specific series of the index for the common sample (1999:1 - 2003:12) are given in Table 3.

If the correlations are examined, the results depend to a great extend on the reverence index. If the correlation with the unweighted average is considered where every country gets equal weight, the new EU countries show a strong relationship with the average. The picture is nearly reversed, if the correlation with the weighted index is considered. The latter is more appropriate because this will be the situation the Governing Council is confronted with in an enlarged monetary union. The weighted averages are the euro-wide variables which are the basis for the decisions about the next change of the interest rate. In this case, the new EU countries exhibit a rather low correlation. If we do not change the group size and assume that the group with the highest voting weight should be composed of countries which are closest to the average economic development of the euro area, the classification of countries is given by

- Group I:

EMU-22/EMU-25: Austria, Belgium, Finland, France, Germany

\footnotetext{
${ }^{3}$ Source: Eurostat, short-term indicators

${ }^{4}$ Industrial production series: seasonally adjusted, index $(2000=100)$, excluding construction, Source: Eurostat, short-term indicators.
} 
Table 3: Correlation with the European average.

\begin{tabular}{|l|c||l|c|}
\hline \multicolumn{4}{|c|}{ EMU-25 } \\
\hline \multicolumn{2}{|c|}{ correlation with } & \multicolumn{2}{c|}{ correlation with } \\
the weighted average & \multicolumn{2}{c|}{ the average } \\
\hline Germany & 0.91 & Finland & 0.93 \\
Austria & 0.90 & Slovenia & 0.91 \\
France & 0.83 & Belgium & 0.84 \\
Finland & 0.77 & Czech Rep. & 0.83 \\
Belgium & 0.73 & Austria & 0.74 \\
\hline Sweden & 0.72 & Germany & 0.72 \\
Ireland & 0.71 & Poland & 0.71 \\
Slovenia & 0.70 & Estonia & 0.67 \\
Luxembourg & 0.69 & Hungary & 0.64 \\
Italy & 0.67 & Luxembourg & 0.64 \\
Spain & 0.66 & Denmark & 0.61 \\
Greece & 0.64 & Ireland & 0.58 \\
Netherlands & 0.60 & Lithuania & 0.51 \\
Portugal & 0.60 & Slovakia & 0.39 \\
Estonia & 0.53 & Netherlands & 0.35 \\
Denmark & 0.49 & Spain & 0.33 \\
Czech Rep. & 0.48 & France & 0.33 \\
Cyprus & 0.36 & Cyprus & 0.33 \\
\hline Latvia & 0.22 & Sweden & 0.25 \\
Lithuania & 0.22 & Latvia & 0.23 \\
Poland & 0.06 & Italy & 0.22 \\
UK & 0.05 & Portugal & 0.18 \\
Hungary & 0.04 & Greece & 0.12 \\
Slovakia & -0.13 & UK & -0.34 \\
\hline
\end{tabular}

\begin{tabular}{|c|c|c|c|}
\hline \multicolumn{4}{|c|}{ EMU-22 } \\
\hline \multicolumn{2}{|c|}{$\begin{array}{c}\text { correlation with } \\
\text { the weighted average }\end{array}$} & \multicolumn{2}{|c|}{$\begin{array}{l}\text { correlation with } \\
\text { the average }\end{array}$} \\
\hline Austria & 0.93 & Finland & 0.92 \\
\hline Germany & 0.90 & Slovenia & 0.90 \\
\hline Finland & 0.83 & Czech Rep. & 0.84 \\
\hline France & 0.80 & Belgium & 0.83 \\
\hline Belgium & 0.77 & Poland & 0.74 \\
\hline Ireland & 0.77 & Austria & 0.71 \\
\hline Slovenia & 0.76 & Germany & 0.69 \\
\hline Luxembourg & 0.73 & Hungary & 0.67 \\
\hline Spain & 0.68 & Estonia & 0.67 \\
\hline Italy & 0.67 & Luxembourg & 0.62 \\
\hline Greece & 0.59 & Ireland & 0.55 \\
\hline Netherlands & 0.57 & Lithuania & 0.51 \\
\hline Portugal & 0.56 & Slovakia & 0.41 \\
\hline Estonia & 0.55 & Cyprus & 0.32 \\
\hline Czech Rep. & 0.53 & Netherlands & 0.31 \\
\hline Cyprus & 0.41 & Spain & 0.31 \\
\hline Lithuania & 0.23 & France & 0.29 \\
\hline Latvia & 0.19 & Latvia & 0.22 \\
\hline Poland & 0.15 & Italy & 0.19 \\
\hline Hungary & 0.10 & Portugal & 0.15 \\
\hline Slovakia & -0.07 & Greece & 0.07 \\
\hline
\end{tabular}

- Group II:

EMU-22: Cyprus, Czech Republic, Estonia, Greece, Ireland, Italy, Luxembourg, Netherlands, Portugal, Slovenia, Spain

EMU-25: Cyprus, Czech Republic, Denmark, Estonia, Greece, Ireland, Italy, Luxembourg, Netherlands, Portugal, Slovenia, Spain, Sweden

- Group III:

EMU-22: Hungary, Latvia, Lithuania, Poland, Slovakia

EMU-25: Hungary, Latvia, Lithuania, Poland, Slovakia, UK

With this classification scheme it is not only the "big" countries who receive a seat in the first group. This is due to the fact that voting power is now primarily determined by proximity to the average of the monetary union rather than by the size of the country. By reason of the similar economic conditions in these countries, the governors should have the same interest in the decision-making process regarding 
the interest rate. Therefore, it should not matter much besides representation of the population which governor makes the decision. Even representation should not be a big problem, because the people in the countries of one group should have the same interest with respect to monetary policy.

The difference between the correlation coefficient and the intertemporal voting share is shown in Figure 4 and 5. As a comparison with the original grouping scheme shows there arises a different pattern for the gap between voting weight and economic weight, the latter now represented by the correlation coefficient. Now, there are countries in the first and in the second group which are under- as well as overrepresented if the correlation with the average is the standard. Still, the governors in the third group have a higher voting share than the economic weight suggests. If the governors should represent the average economic situation in the euro area, the correlation with this average seems an appropriate measure. But a note of caution is in order: The sample of five years is definitely too short to address a whole business cycle and, therefore, this result has a very preliminary character.

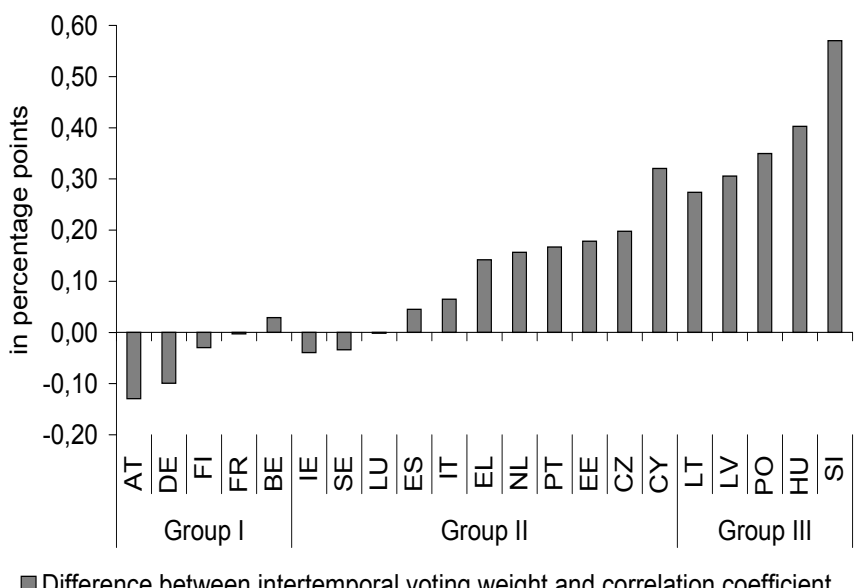

Figure 4: Difference between the intertemporal voting share and the correlation coefficient with the average for the EMU-22.

As the analysis of the deviations and the correlations show, the classification of the member states according to different economic indices gives different results. There is no possibility to decide which classification scheme is best because the indices measure the economic situation in different ways. Each scheme may have its justifications because they pursue individually distinctive goals, e.g. representation of the relative population size or representation of similarities in the economic situation and the preferences of the population. To assess the effects of the rotation scheme 


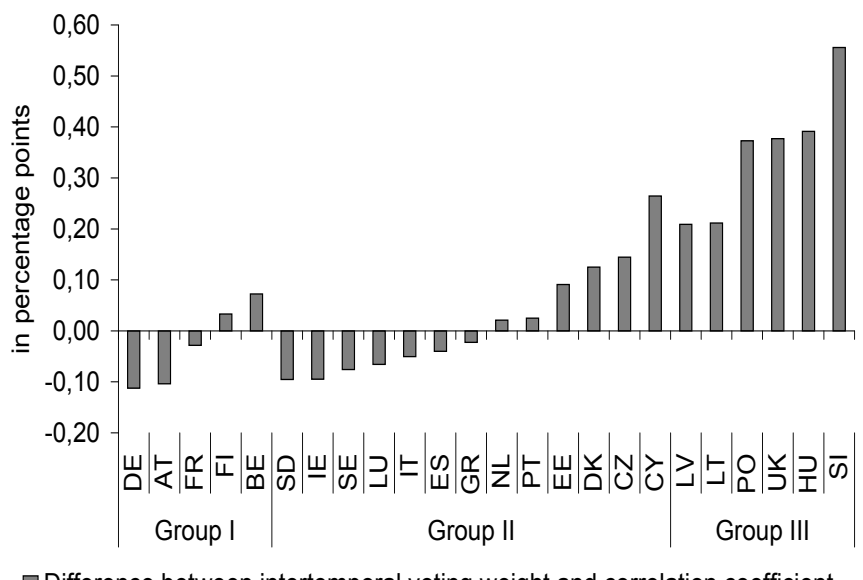

Figure 5: Difference between the intertemporal voting share and the correlation coefficient with the average for the EMU-25.

better, we go beyond the analysis of voting weights connected to economic weight and apply voting power indices.

\section{$3.2 \quad$ Voting power}

\subsubsection{Change of Voting Power due to Enlargement and Rotation}

The second part in evaluating the ECB reform is characterised by the use of voting power indices. The voting weight of a governor could be used to measure the difference between the economic or population weight and the weight a governor has in the voting process in an approximate way. But to investigate the power a governor has on the decisions of the central bank a priori, voting power indices are a better choice because they account for the distribution of voting weights and, therefore, power in the different scenarios. As the analysis shows, the average voting power and the intertemporal voting weight are very similar.

There are different indices to measure voting power. The most common indices are the Shapley-Shubik index (Shapley and Shubik 1954) and the Banzhaf index/measure (Banzhaf 1965) and their extensions and refinements ${ }^{5}$. Where the Banzhaf measure indicates the absolute power of influence on the results of a vote, the Banzhaf index measures the relative share of total power a governor possesses. Both indices rely on the concept of the pivotal voter. A voter is pivotal in case of the

\footnotetext{
${ }^{5}$ See Felsenthal and Machover (1998) for an encompassing analysis of voting power indices.
} 
Shapley-Shubik index if her agreement turns the coalition from a loser into a winner. For the Banzhaf index a voter is pivotal if a change of the vote makes the turn from a winning to a losing coalition. The interpretation of the indices can also follow a different line of reasoning, the assumption with regard to the probability distribution of approval (Straffin Jr. 1994, p. 1137): If the voters behave independent of each other, the power is best measured by the Banzhaf index. If the probability that the voters agree to a proposal is the same for all, the individual effect can be assessed by the Shapley-Shubik index (homogeneity assumption).

We concentrate on decisions pertaining to interest rate changes. If interest rate decisions are taken, the Banzhaf-Index seems to be appropriate, because we want to investigate if a governor is critical for the agreement about the next interest rate step (Fedeli and Forte 2001, p. 13). On the other hand, Brueckner (2001) argues that the Shapley-Shubik index is more appropriate. This is the case if the members of the Council agree on a proposal with the same probability because the countries are highly integrated. Furthermore, a voter is powerful if its leaving the coalition leads to a failure of the proposal. We calculate both indices to asses the voting power with regard to two different situations where the Governing Council decides.

In the following, we investigate whether voting weight and voting power differ, in which respect, and the effects of the ECB reform on representation. That is, we do not change the rotation scheme but calculate the indices for the rotation as it will be implemented according to the decision of the Council of Ministers. ${ }^{6}$ To assess the voting power of the Council members, it is important to account for the possibility that the board member could support a governor if an interest rate change is decided. Therefore, the crucial difference between the scenarios is the behaviour of the board. The first possibility is to assume that the board only cares about the EMU average. The second possibility is to presume that the board members behave as national agents and support the decision of the national central bank governor if she originates from the country that the board member represents. In this case, the votes of a national central bank governor are assumed to add up from that of the governor and that of the board member. Of course, not every board member will support the governor of her country of origin. It is imaginable that only a part of the board members behave as national partisans.

The most interesting case is that of a Council with partisan board members and rotation. The president and the board members have to decide if they should behave as partisan. But they cannot influence to which group the governor of their country of origin belongs to and, therefore, not on the voting weight they get allocated. These coalitions of board member/president and governor generate different voting power indices for the national governors depending on the number of board members

\footnotetext{
${ }^{6}$ For an investigation regarding alternative rotation schemes see Berger et al. (2002) or Baldwin et al. (2001).
} 
supporting a governor and the distribution of the votes on the different groups. To assess the development of voting power, we calculate the average voting power for a member of the Governing Council representing one country with rotation and partisan board members.

The following scenarios are limited to the status quo (EMU-12) and the enlargement of the monetary union by 10 member (EMU-22).

A Status quo: 12 governors and six board members.

A1: EMU-12 without rotation, non-partisan board members.

A2: EMU-12 without rotation and partisan board members.

B Enlargement by 10 governors without rotation: 22 governors and six board members.

B1: EMU-22 without rotation, non-partisan board members.

B2: EMU-22 without rotation and partisan board members.

C Enlargement by 10 governors with rotation: 22 governors and six board members.

C1: EMU-22 with rotation, non-partisan board members.

C2: EMU-22 with rotation and partisan board members.

In the status quo, no rotation is intended and, therefore, the scenarios contain only the distinction between partisan board members and non-partisan board member (scenario A). If the board members behave as national partisans, they vote in line with the governor of their country of origin (scenario A2). That is the same as if the members of the Governing Council are reduced, but the respective governors have a higher voting weight. No governor will be supported by more than one board member because the board member will assist the governor of her country of origin. In scenario A1, the board members make their own decisions without connection to their country of origin. The next collection of scenarios is given by situations where the Council is enlarged by ten new governors but rotation is not applied. Again, the board members could behave as partisans (B2) or not (B1). The last both scenarios are that for an enlarged decision-making body and rotation takes place (scenario $\mathrm{C}$ ). If the board members support the decisions of the national governors, the voting power depends on the group in which the governor is placed (scenario C2).

We assume that the decisions of the Governing Council are made with simple majority as prescribed in the statute. Because of the growing number of members it 
seems not unreasonable to assume that the decision rule of simple majority will play a larger role because unanimity is harder to achieve in a larger decision-making body.

The weighting of the votes in case of rotation is done by the intertemporal voting share. The president of the central bank gets double weight of a board member because he decides in case of a tie. The threshold is determined by simple majority, that is in case of the EMU-12 ten votes, in case of the EMU-22 15 votes without rotation and 11 votes with rotation.

Because the results for the normalised Banzhaf index and the Shapley-Shubik index are nearly identical (see appendix), we show only the Banzhaf index/normalised Banzhaf index and the Banzhaf measure/non-normalised Banzhaf index for interpretation (Felsenthal and Machover 1998, p. 39). Even if the Banzhaf index and the Shapley-Shubik index have similar values, the interpretation is different. The Banzhaf index indicates the power of policy-seeking and the Shapley-Shubik index that of office-seeking (Felsenthal and Machover 1998, p. 18).

In the following, the change of voting power is analysed for the national central bank governors and the board. We compare the status quo of a monetary union of 12 countries with an enlarged monetary union where ten new governors join the Council. To assess the effect of the rotation scheme, the voting power of the Council members is also calculated for the EMU-22 but without rotation. All three basic scenarios are considered for non-partisan (see appendix Table 5, 6, and 9) and partisan board members (see appendix Table 7, 8, and 10).

A comparison between the voting power and the voting weight for the different scenarios leads to varying results (see Figure 6 - 9). For scenarios where only one distribution of voting weights is possible, e.g. if the board members do not support the national central bank governors, voting weight and voting power are more or less identical for the three basic scenarios, at least for the Banzhaf index. In this case, every Council members loses voting power if more members join the decision-making body. With the introduction of the rotation scheme, the voting weight/power develops different for the Council members. The president as well as the other board members regain voting power to a relatively large extent. The governors of the first group also have higher indices in the EMU with rotation than without. But the gain is small. Governors of the second and third group lose power if the rotation scheme is introduced. This effect is particularly strong for governors of the third group.

If the board members behave as national partisans, there is a difference in the level of voting power compared to the non-partisan scenario. The Banzhaf index measures a higher power for every member of the Governing Council. Moreover, governors of the first group regain voting power to a larger scope than in case of a non-partisan board. For governors of the second group the support by board members leads to 
a gain of voting power after the introduction of rotation. Without support, they lose power. Even the governors of the third group are better off with rotation because their loss of voting power is not as attenuated as in the former case. If the development of voting power and voting weight is compared, the similar change of both measures as seen in the non-partisan scenario is broken. This is evident in case of the voting power of governors of the second group which rises, whereas the voting weight indicates a loss of political weight.

The Banzhaf index indicates a drop of relative power for the president and the other board members. But as the Banzhaf measure indicates, every board member including the president are a priori more able to tip the balance in the decisions in case of rotation than under the present decision-making process. This is the case whether they behave as national partisans or not. The a priori voting power of governors of the third group is reduced if the Council is enlarged and this development continues if the rotation scheme is introduced.

This is the same pattern as the relative voting power shows. For the first group of governors, there is no significant difference in the behaviour of the relative and the a priori power. But for the governors of the second group, there is no recovering of power with the introduction of the rotation as in the case of the relative voting power. Not surprisingly, the Banzhaf measure also leads to a higher level of voting power than the normalised Banzhaf index for every member of the Council.

The small difference between the development of the voting power indices and the voting weight with the enlargement of the Council can be attributed to the averaging over the different values of the voting power indices in case of a partisan board. Where the voting weight can only account for the basic case, the voting power indices differentiate between varying constellations of partisan board members and account for the variance of voting power.

The high voting power of the board, especially of the president, could be seen as a concession for an expert committee deciding about monetary policy. If the board only decides with respect to the necessities of the monetary union as a whole whereas the national central bank governors are seen as pursuing national interests to a certain extent, the fortification of the board protects monetary policy against the influence of national interests. 


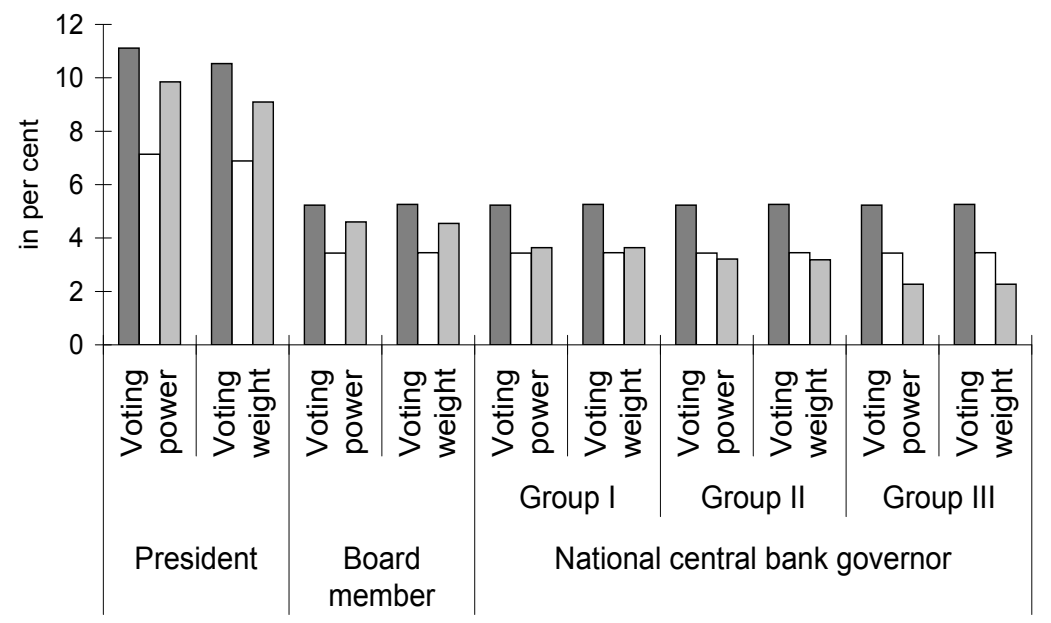

$\square \mathrm{A} 1$ - EMU-12 $\square \mathrm{B} 1$ - EMU-22 without rotation $\square \mathrm{C} 1$ - EMU-22 with rotation

Figure 6: Voting weight and voting power measured by the normalised Banzhaf index in the EMU-12 (A1), EMU-22 without rotation (B1) and EMU-22 with rotation (C1) and non-partisan board members.

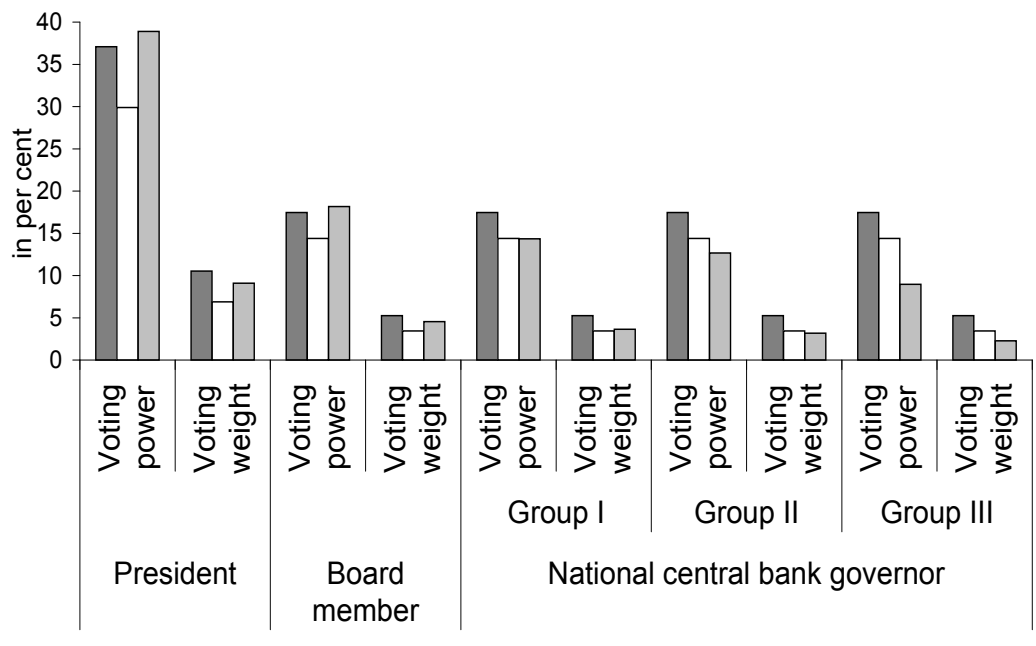

$\square \mathrm{A} 1$ - EMU-12 $\square \mathrm{B} 1$ - EMU-22 without rotation $\square \mathrm{C} 1$ - EMU-22 with rotation

Figure 7: Voting weight and voting power measured by the non-normalised Banzhaf index in the EMU-12 (A1), EMU-22 without rotation (B1) and EMU-22 with rotation (C1) and non-partisan board members. 


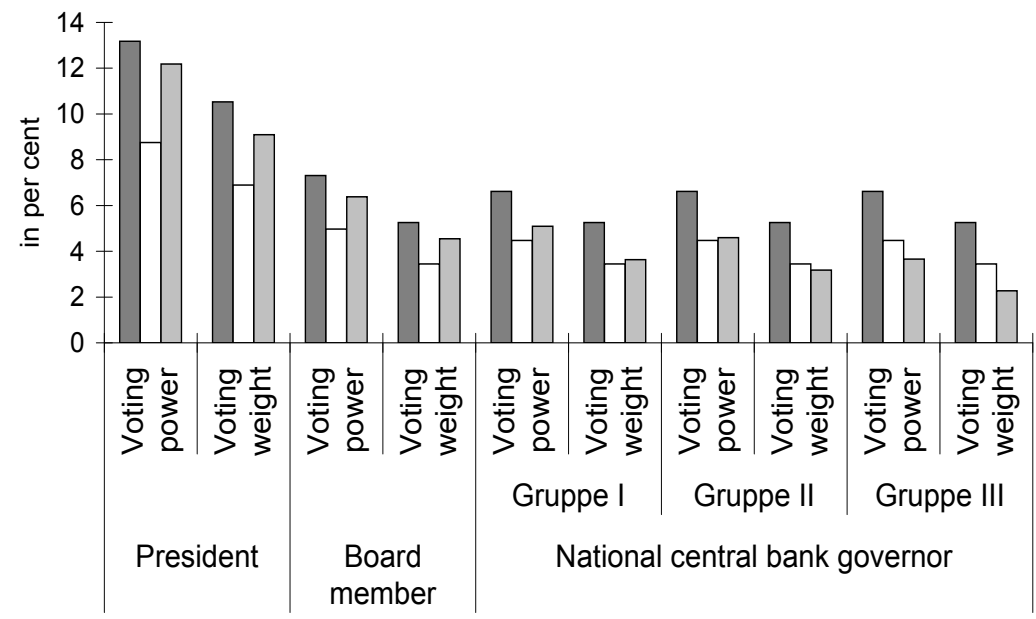

$\square \mathrm{A} 2$ - EMU-12 $\square \mathrm{B} 2$ - EMU-22 without rotation $\square \mathrm{C} 2$ - EMU-22 with rotation

Figure 8: Voting weight and voting power measured by the normalised Banzhaf index in the EMU-12 (A2), EMU-22 without rotation (B2) and EMU-22 with rotation (C2) and partisan board members.

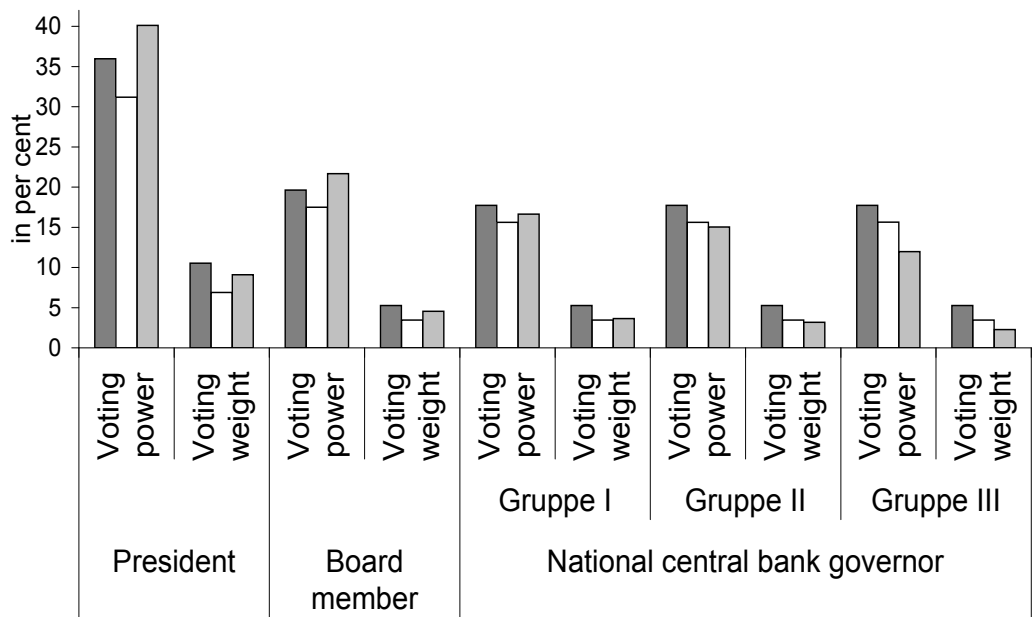

$\square \mathrm{A} 2$ - EMU-12 $\square \mathrm{B} 2$ - EMU-22 without rotation $\square \mathrm{C} 2$ - EMU-22 with rotation

Figure 9: Voting weight and voting power measured by the non-normalised Banzhaf index in the EMU-12 (A2), EMU-22 without rotation (B2) and EMU-22 with rotation (C2) and partisan board members. 
Summing up, the introduction of the rotation scheme in the enlarged monetary union leads to losses of voting power for the governors in group III. For the governors of the other two groups, the development of voting power for the different scenarios depends on the assumption about the behaviour of the board. If the board members support the national central bank governors, their voting power increases compared to an enlarged decision-making body without rotation. Furthermore, if there are national partisan board members, the level of voting power of the Council members increases in every case. The latter fact suggests, that it is not unreasonable to expect that the board could behave partisan.

Besides the efficiency of the decision-making process, the deviation of economic and political weight is one reason for the reform. If the political and economic weight are identical, it does not matter for the results of the interest rate decision if the governors are influenced by the economic situation in their country of origin: The interest rate of the euro area resulting from the decisions of the ECB Council is a weighted average of the interest rates preferred by the governments and the board $i_{b d}^{*}$, where the weighting is done according to the parameter $a$ and $1-a, 0 \leq a \leq 1$, indicating the relative political power of board and national central bank governors as a whole. The interest rates the governors pursue, $i_{i}^{*}$, are aggregated with the help of the respective individual political weight of a governor in the decision process, $b_{i}$. Therefore, we can write the interest rate of the euro area as the outcome of the Council decisions as follows:

$$
i^{*}=a \sum_{i} b_{i} i_{i}^{*}+(1-a) i_{\text {board }}^{*}
$$

Furthermore, we assume that the governors and the board decide about the interest rate according to a Taylor rule and determine the interest rates by the following equations, where the governors look at country-specific as well as euro area variables and the board on euro area variables only:

$$
\begin{aligned}
i_{i}^{*} & =c_{i}\left(\alpha_{i}+\beta_{i} \pi_{i}+\gamma_{i} \bar{y}_{i}\right)+\left(1-c_{i}\right)\left(\alpha_{i}+\beta_{i} \pi+\gamma_{i} \bar{y}\right) \\
i_{b d}^{*} & =\alpha_{b d}+\beta_{b d} \pi+\gamma_{b d} \bar{y}
\end{aligned}
$$

The Taylor interest rate depends on the inflation rate $\pi$ and the output gap $\bar{y}$. The coefficients of the inflations rates and output gaps incorporate the preferences of the central banker regarding the inflation and the output gap. The weight a governor 
assigns to the country-specific variables is denoted by $c_{i}$. This leads to an equation for the euro area interest rate of

$$
\begin{aligned}
i^{*}= & a \sum_{i} b_{i}\left[c_{i}\left(\alpha_{i}+\beta_{i} \pi_{i}+\gamma_{i} \bar{y}_{i}\right)+\left(1-c_{i}\right)\left(\alpha_{i}+\beta_{i} \pi+\gamma_{i} \bar{y}\right)\right] \\
& +(1-a)\left(\alpha_{b d}+\beta_{b d} \pi+\gamma_{b d} \bar{y}\right) \\
= & a \sum_{i} b_{i} \alpha_{i}+a \sum_{i} b_{i} \beta_{i} c_{i} \pi_{i}+a \sum_{i} b_{i} \gamma_{i} c_{i} \bar{y}_{i}+\pi a \sum_{i} b_{i} \beta_{i}\left(1-c_{i}\right) \\
& +\bar{y} a \sum_{i} b_{i} \gamma_{i}\left(1-c_{i}\right)+(1-a)\left(\alpha_{b d}+\beta_{b d} \pi+\gamma_{b d} \bar{y}\right) .
\end{aligned}
$$

Furthermore, we assume that a governor does not react different to the inflation rate of the euro area and the country-specific value and the same for the output gap. The difference between the decision makers is given by the variables they look at.

The political weight reflects the influence the country-specific variables exert on the preferred interest rate, $a b_{i} \beta_{i} c_{i}$, and the political weights sum up to one with $a \sum b_{i} \beta_{i} c_{i}=1$. If the political and the economic weight is identical, then $a \sum b_{i} \beta_{i} c_{i} \pi_{i}=\pi$ and $a \sum b_{i} \gamma_{i} c_{i} \bar{y}_{i}=\bar{y}$ and the equation for the Taylor interest rate of the euro area simplifies as follows

$$
\begin{aligned}
i^{*} & =a \sum b_{i} \alpha_{i}+(1-a) \alpha_{b d}+\left[a \sum b_{i} \beta_{i}+(1-a) \beta_{b d}\right] \pi \\
& +\left[a \sum b_{i} \gamma_{i}+(1-a) \gamma_{b d}\right] \bar{y} .
\end{aligned}
$$

In this case, the interest rate of the euro area depends only on aggregated variables, regardless how much weight the Council members assign to the euro area or countryspecific variables.

A comparison of the economic and population weight with the voting power as an approximation for the political weight can only be done for the Banzhaf and Shapley-Shubik index because these indices sum up to one just as the the economic and population shares do. In addition, the classification of governors into groups leads to a generalisation because all members of a group get the same voting power even if their economic and population weights differ. We compare the average of the population weight and the average of the economic weight of the different groups with the respective Banzhaf index (see Figure 10 and 11). Thereby, the statements are the same for the economic and the population weight. 


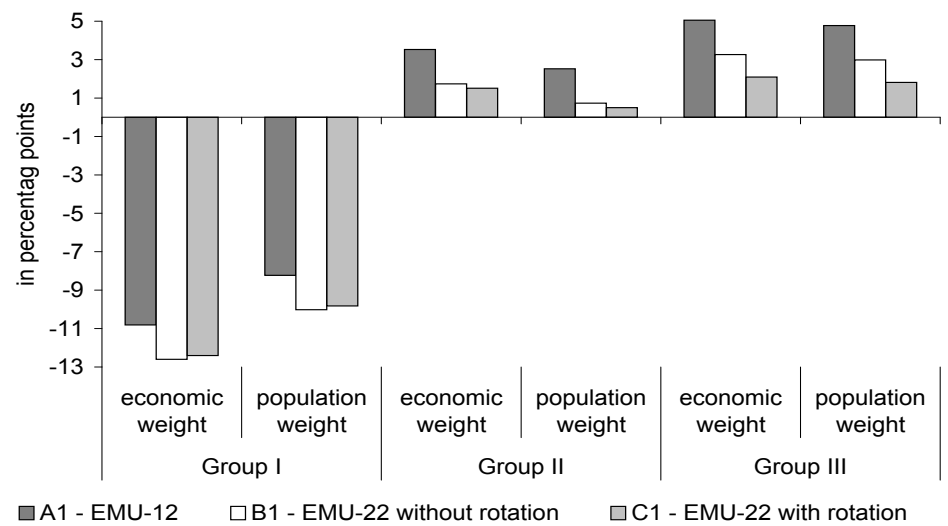

Figure 10: The difference between voting power measured by the Banzhaf index and average economic and population weight for the EMU-12 (A1), EMU-22 without rotation (B1) and EMU-22 with rotation (C1) and non-partisan board members.

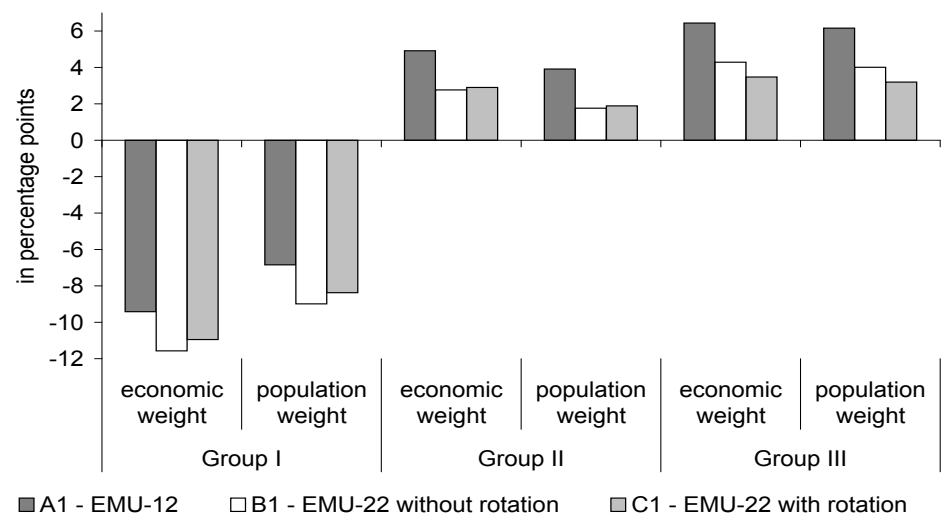

Figure 11: The difference between voting power measured by the Banzhaf index and average economic and population weight for the EMU-12 (A2), EMU-22 without rotation (B2) and EMU-22 with rotation (C2) and partisan board members.

For the governors of group I, the loss of voting power caused by the enlargement compared to the status quo leads to a worsening of the representation of the countries with respect to the economic as well as population weight by their governors. The loss is partly offset by the introduction of the rotation scheme. The loss of voting power for the governors of group III leads to an adjustment of political and economic/population weight. This is an advantage in terms of representation. Because the governors of group II also lose voting power compared to the EMU-12, 
the gap between the economic and population share and the voting power is closed but not to a large extend and only if there is no partisan behaviour of the board. All in all, the rotation scheme is only appropriate to a certain extent to account for the adjustment between economic/population share and political influence on the interest rate decisions.

\section{Conclusion}

The reform of the ECB designed to meet the challenges of the enlargement of the EMU by up to 13 members has been severely criticised. The criticism mostly refers to the self-imposed goals of the ECB, e.g. representation, transparency, 'one person - one vote', and efficiency of the decision process. Especially the economic criteria for the allocation of national central bank governors into different groups of the rotation scheme have the reputation of being political motivated. In the paper, we ask if there would be a significantly different classification of the member states, if other economic criteria would be used. As the analysis shows, the use of different economic criteria does not lead to a reversed ordering of the countries compared to the ECB proposal and, therefore, to a much different allocation of the governors to the groups. The use of the deviation from the average economic situation would lead to more changes in the group composition than the use of the synchronisation of the economic development. But even then, most of the countries would move into the next higher or lower group. A change from the first to the third group or reverse would be a rare exception. If the similarity in the economic development is used, small member states would get a higher weight. But the third group of governors with the smallest voting weight would predominantly be composed of the new EU member states as in the accepted reform.

The second approach to evaluate the reform is the use of voting power indices to trace the development of the political influence of a Council member on interest rate decisions influenced by the enlargement of the Council and the introduction of the rotation scheme. As it is shown, the board is the only part of the Council which unanimously gains because of the introduction of rotation. This could be interpreted as a movement towards an expert committee if one assumes that the board members are less prone to influences of national interests. For the national central bank governors, all votes lose power with the enlargement so that the underrepresentation of countries of group I is aggravated but this development is slightly diminished or at least not amplified by the introduction of the rotation scheme. For the group III of governors, the over-representation is further reduced by the introduction of the rotation scheme. 


\section{Appendix}

Calculation of the deviations The inflation rate and growth rate of the respective monetary union are determined by a weighted average of the countryspecific series. For the calculation of the EMU average of the inflation rate, the Eurostat weighting scheme of the year 2004 for the HICP is used because only this scheme includes the weights for the new member states (Eurostat 2004a and 2004b). The weighting scheme of the growth rate is also the one used by Eurostat (Eurostat 2004c). Then, the country-specific deviations $d e_{i}$ from the respective average of the monetary union are calculated, $d e_{i}=\left|e s_{i}-e s\right|$. Summing the deviations and determining the relative share of a country $r d e_{i}$ on the aggregated deviation de gives the relative deviation of a country, $r d e_{i}=d e_{i} / d e$.

Table 4: Abbreviations

$\begin{array}{llll}\text { AT } & \text { Austria } & \text { SD } & \text { Sweden } \\ \text { BE } & \text { Belgium } & \text { UK } & \text { United Kingdom } \\ \text { FI } & \text { Finland } & \text { CZ } & \text { Czech Republic } \\ \text { FR } & \text { France } & \text { CY } & \text { Cyprus } \\ \text { DE } & \text { Germany } & \text { HU } & \text { Hungary } \\ \text { EL } & \text { Greece } & \text { LV } & \text { Latvia } \\ \text { IE } & \text { Ireland } & \text { LT } & \text { Lithuania } \\ \text { IT } & \text { Italy } & \text { MT } & \text { Malta } \\ \text { LU } & \text { Luxembourg } & \text { SI } & \text { Slovakia } \\ \text { NL } & \text { Netherlands } & \text { SE } & \text { Slovenia } \\ \text { PT } & \text { Portugal } & \text { EE } & \text { Estonia } \\ \text { ES } & \text { Spain } & \text { PO } & \text { Poland } \\ \text { DK } & \text { Denmark } & & \end{array}$

Table 5: A1 - Voting power in the EMU-12 with non-partisan board members.

\begin{tabular}{|l|c|c|c|c|}
\hline & $\begin{array}{c}\text { Voting } \\
\text { Weight }\end{array}$ & $\begin{array}{c}\text { Banzhaf } \\
\text { measure }\end{array}$ & $\begin{array}{c}\text { Banzhaf } \\
\text { index }\end{array}$ & $\begin{array}{c}\text { Shapley- } \\
\text { Shubik } \\
\text { index }\end{array}$ \\
\hline President & 2 & 0.3709 & 0.1111 & 0.1111 \\
Board member & 1 & 0.1746 & 0.0523 & 0.0523 \\
NB governor & 1 & 0.1746 & 0.0523 & 0.0523 \\
\hline Number of players & & \multicolumn{3}{|c|}{18} \\
Quota & & \multicolumn{3}{|c}{10} \\
\hline
\end{tabular}

The calculation is done using the algorithm of Tannenbaum (1997) and own modifications. 
Table 6: B1 - Voting power in the EMU-22 with non-partisan board members.

\begin{tabular}{|l|c|c|c|c|}
\hline & $\begin{array}{c}\text { Voting } \\
\text { Weight }\end{array}$ & $\begin{array}{c}\text { Banzhaf } \\
\text { measure }\end{array}$ & $\begin{array}{c}\text { Banzhaf } \\
\text { index }\end{array}$ & $\begin{array}{c}\text { Shapley- } \\
\text { Shubik } \\
\text { index }\end{array}$ \\
\hline President & 2 & 0.2989 & 0.0714 & 0.0714 \\
Board member & 1 & 0.1439 & 0.0344 & 0.0344 \\
NB governor & 1 & 0.1439 & 0.0344 & 0.0344 \\
\hline Number of players & & \multicolumn{3}{|c|}{28} \\
Quota & & \multicolumn{3}{|c}{15} \\
\hline
\end{tabular}

The calculation is done using the algorithm of Tannenbaum (1997) and own modifications.

Table 7: A2 - Average voting power in the EMU-12 with partisan board members.

\begin{tabular}{|l|c|c|c|c|}
\hline & $\begin{array}{c}\text { Voting } \\
\text { Weight }\end{array}$ & $\begin{array}{c}\text { Banzhaf } \\
\text { measure }\end{array}$ & $\begin{array}{c}\text { Banzhaf } \\
\text { index }\end{array}$ & $\begin{array}{c}\text { Shapley- } \\
\text { Shubik } \\
\text { index }\end{array}$ \\
\hline President & 2 & 0.3597 & 0.1318 & 0.1327 \\
Board member & 1 & 0.1962 & 0.0731 & 0.0732 \\
NB governor & 1 & 0.1773 & 0.0662 & 0.0662 \\
\hline Quota & & \multicolumn{3}{|c|}{10} \\
\hline
\end{tabular}

The calculation is done using the algorithm of Tannenbaum (1997) and own modifications.

Table 8: B2 - Average voting power in the EMU-22 with partisan board members.

\begin{tabular}{|l|c|c|c|c|}
\hline & $\begin{array}{c}\text { Voting } \\
\text { Weight }\end{array}$ & $\begin{array}{c}\text { Banzhaf } \\
\text { measure }\end{array}$ & $\begin{array}{c}\text { Banzhaf } \\
\text { index }\end{array}$ & $\begin{array}{c}\text { Shapley- } \\
\text { Shubik } \\
\text { index }\end{array}$ \\
\hline President & 2 & 0.3118 & 0.0875 & 0.0877 \\
Board member & 1 & 0.1750 & 0.0497 & 0.0499 \\
NB governor & 1 & 0.1562 & 0.0447 & 0.0447 \\
\hline Quota & & \multicolumn{3}{|c|}{15} \\
\hline
\end{tabular}

The calculation is done using the algorithm of Tannenbaum (1997) and own modifications. 
Table 9: C1 - Voting power in the EMU-22 with non-partisan board members and rotation.

\begin{tabular}{|l|c|c|c|c|}
\hline & $\begin{array}{c}\text { Voting } \\
\text { Weight }\end{array}$ & $\begin{array}{c}\text { Banzhaf } \\
\text { measure }\end{array}$ & $\begin{array}{c}\text { Banzhaf } \\
\text { index }\end{array}$ & $\begin{array}{c}\text { Shapley- } \\
\text { Shubik } \\
\text { index }\end{array}$ \\
\hline President & 20 & 0.3889 & 0.0985 & 0.0976 \\
Board member & 10 & 0.1816 & 0.0460 & 0.0463 \\
NB governor group I & 8 & 0.1435 & 0.0364 & 0.0364 \\
NB governor group II & 7 & 0.1268 & 0.0321 & 0.0321 \\
NB governor group III & 5 & 0.0897 & 0.0227 & 0.0226 \\
\hline Number of players & & \multicolumn{3}{|c|}{28} \\
Quota & & \multicolumn{3}{|c|}{110} \\
\hline
\end{tabular}

The calculation is done using the algorithm of Tannenbaum (1997) and own modifications.

Table 10: C2 - Average voting power in the EMU-22 with partisan board members and rotation.

\begin{tabular}{|l|c|c|c|c|}
\hline & $\begin{array}{c}\text { Voting } \\
\text { Weight }\end{array}$ & $\begin{array}{c}\text { Banzhaf } \\
\text { measure }\end{array}$ & $\begin{array}{c}\text { Banzhaf } \\
\text { index }\end{array}$ & $\begin{array}{c}\text { Shapley- } \\
\text { Shubik } \\
\text { index }\end{array}$ \\
\hline President & $28 / 27 / 25 / 20$ & 0.4013 & 0.1218 & 0.1218 \\
Board Member & $18 / 17 / 15 / 10$ & 0.2168 & 0.0638 & 0.0638 \\
\hline NB Governor group I & $28 / 18 / 8$ & 0.1663 & 0.0509 & 0.0510 \\
NB Governor group II & $27 / 17 / 7$ & 0.1503 & 0.0460 & 0.0460 \\
NB Governor group III & $25 / 15 / 5$ & 0.1197 & 0.0366 & 0.0364 \\
\hline Quota & & \multicolumn{3}{|c|}{110} \\
\hline
\end{tabular}

The calculation is done using the algorithm of Tannenbaum (1997) and own modifications. 


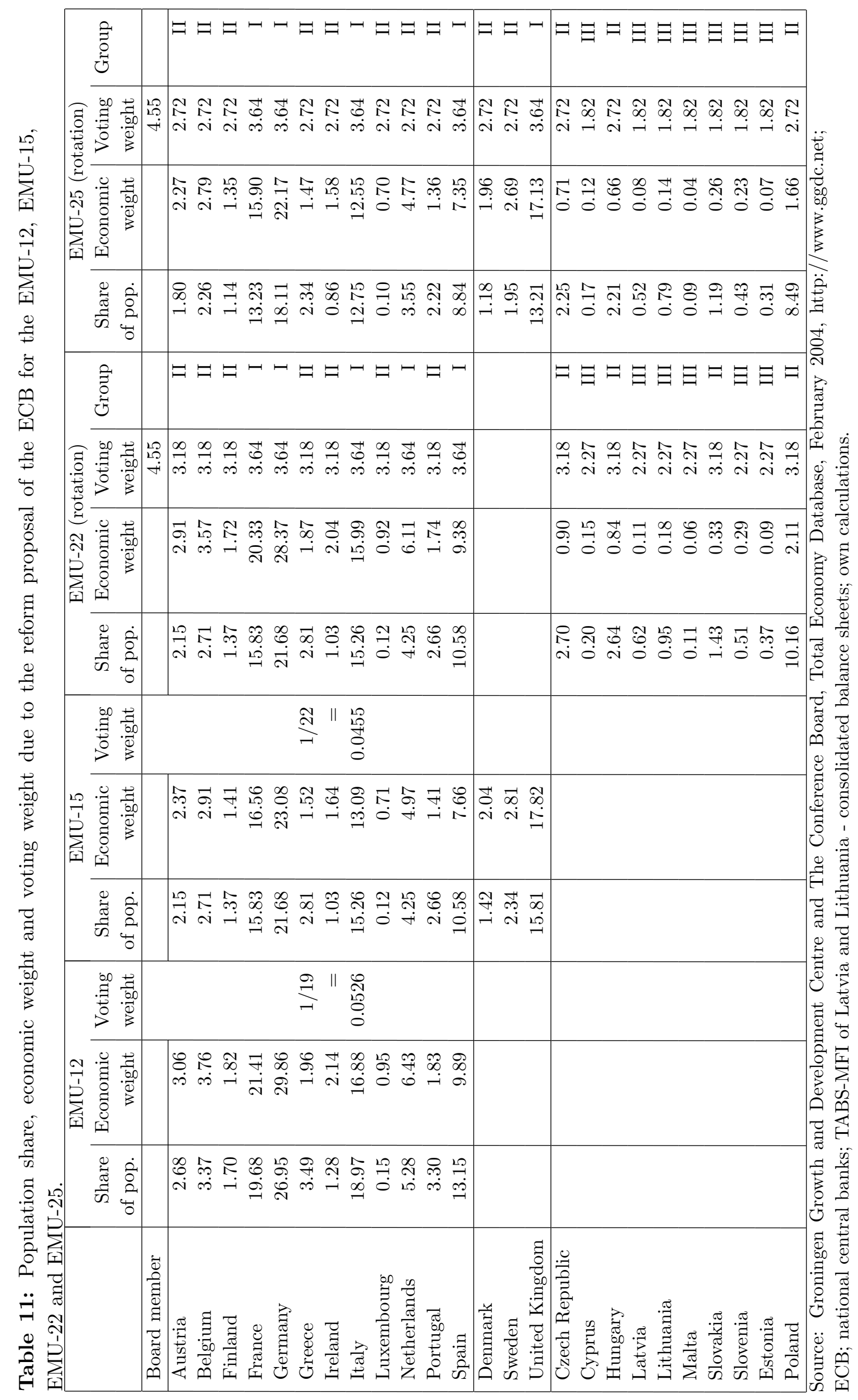




\section{References}

Baldwin, R. E., E. Berglöf, F. Giavazzi, and M. Widgrén (2001), Eastern Enlargement and ECB Reform, Swedish Economic Policy Review Vol. 8, 15-50.

Banzhaf, J. F. (1965), Weighted Voting Does not Work: A Mathematical Analysis, Rutgers Law Review Vol. 19, 317-343.

Belke, A., And F. Baumgärtner (2004), Die EZB und die Erweiterung - eine ökonomisch und rechtliche Kurzanalyse des neuen Rotationsmodells, integration Vol. 27(1-2), 75-84.

Berger, H. (2002), The ECB and Euro-Area Enlargement, IMF Working Paper $\mathrm{WP} / 02 / 175$.

Berger, H., J. De HaAn, And R. InklaAR (2003), Restructuring the ECB, CESifo Working Paper No. 1084.

Berger, H., and C. Hefeker (2004), One Country, One Vote? Labor Market Structure and Voting Rights in the ECB, CESifo Working Paper No. 1165.

Bindseil, U. (2001), A Coalition-Form Analysis of the "One Country - One Vote" Rule in the Governing Council of the European Central Bank, International Economic Journal Vol. 15(1), 141-164.

Bofinger, P. (2003), Consequences of the Modification of the Governing Council Rules, Briefing Paper for the Committee for Monetary and Economic Affairs (ECON) of the European Parliament, 17 February 2003.

Brueckner, M. (2001), Voting Power in the European Central Bank, in: Holler, M. J., and G. Owen (eds.), Power Indices and Coalition Formation, 341-351.

CouncIL (2003), Decision of the Council, Meeting in the Composition of the Heads of State or Government of 21 March 2003 on an amendment to Article 10.2 of the Stature of the European System of Central Banks and of the European Central Bank, Official Journal of the European Union, 2003/223/EC, L 83/66.

De la Dehesa, G. (2003), The New Governing Rules of the ECB, Briefing Paper for the Committee for Monetary and Economic Affairs (ECON) of the European Parliament, 17 February 2003.

Eurostat (2004a), Euro-zone annual inflation down to 1.6\%, Eurostat News Release 39.

(2004b), Euro-zone annual inflation up to 2.0\%, Eurostat News Release 65. 
(2004c), Gewichtung in den Konjunkturstatistiken nach der Erweiterung, Statistik kurz gefasst, Thema 4, 20.

Fahrholz, C., And P. Mohl (2004), EMU-Enlargement and the Reshaping of Decision-Making within the ECB Governing Council, Ezoneplus Working Paper No. 23.

Farvaque, E., And P. Stanek (2003), High 'n' Dry: A Critical Report on the European Conventions's Monetary Aspects, Paper prepared for the Marc Bloch Center and Walter Hallstein Institut Symposium on "L'avenir de l'Union européenne: pour un bilan critique de la Convention européenne" Berlin, November 2003.

Fedeli, S., And F. Forte (2001), Voting Powers and the Efficiency of the DecisionMaking Process in the European Council of Ministers, European Journal of Law and Economics Vol. 12(1), 5-38.

Felsenthal, D. S., And M. Machover (1998), The Measurement of Voting Power, Cheltenham.

Frenkel, M., and R. Fendel (2003), The New ECB Voting System: Some Room for Improvement, Intereconomics Vol. 38(6), 334-338.

Gros, D. (2003), Reforming the Composition of the ECB Governing Council in View of Enlargement: How Not to Do It!, Briefing Paper for the Committee for Monetary and Economic Affairs (ECON) of the European Parliament, 17 February 2003.

Hefeker, C. (2002), Monetary Policy in a Union of 27: Enlargement and Reform Options, Intereconomics Vol. 37(6), 315-320.

Heinemann, F., and F. Hüfner (2004), Is the View from the Eurotower Purely European? National Divergence and ECB Interest Rate Policy, Scottish Journal of Political Economy Vol. 51(4), 544-558.

Heisenberg, D. (2003), Cutting the Bank Down to Size: Efficient and Legitimate Decision-Making in the European Central Bank After Enlargement, Journal of Common Market Studies Vol. 41(3), 397-420.

Horn, G. A. (2003), Consequences of the Modification of the Governing Council Rules, Briefing Paper for the Committee for Monetary and Economic Affairs (ECON) of the European Parliament, 17 February 2003.

Mangano, G. (1999), Monetary Policy in EMU: a Voting-Power Analysis of Coalition Formation in the European Central Bank, Université de Lausanne, Ecole 
des HEC, Cahiers de Recherches Economiques du Département d'Econométrie et d'Economie politique (DEEP) No. 9908.

Shapley, L. S., And M. Shubik (1954), A Method of Evaluating the the Distribution of Power in a Committee System, American Political Science Review Vol. 48(3), 787-792.

Straffin JR., P. D. (1994), Power and Stability in Politics, in: Aumann, R. and S. Hart (eds.) Handbook of Game Theory, Vol. 2, Chap. 32, 1128-1151, Elsevier.

Tannenbaum, P. (1997), Power in Weighted Voting Systems, The Mathematica Journal Vol. 7(1).

TAYlor, J. B. (1993), Discretion versus Policy Rules in Practice, CarnegieRochester Conference Series on Public Policy Vol. 39, 195-214.

Waldner, V., M. Kocher, And M. Sutter (2003), Rotation Schemes in Politics - An Experimental Examination, Max Planck Institute for Research into Economic Systems Discussion Papers on Strategic Interaction No. 26.

Wyplosz, C. (2003), The New Eurosystem, Briefing Paper for the Committee for Monetary and Economic Affairs (ECON) of the European Parliament, 17 February 2003. 